\title{
Cementation scenarios for New Zealand Cenozoic nontropical limestones
}

STEVEN D. HOOD

\section{CAMPBELL S. NELSON}

Department of Earth Sciences

University of Waikato

Private Bag 3105

Hamilton, New Zealand

Abstract Cenozoic limestones are widely distributed in New Zealand, especially in the Oligocene-earliest Miocene in both islands, and the Pliocene-Pleistocene in North Island. A spectrum of limestone types exists, but all are skeletaldominated $(>70 \%)$, with usually $<20 \%$ interparticle cementmatrix and $<10 \%$ siliciclasts, and they have facies attributes typical of nontropical carbonates. The range of diagenetic features identified within the limestones is the basis for assigning them to a small number of "end-member" cementation classes that are inferred to be associated with four, broad, diagenetic settings.

Class I limestones have very open fabrics dominated by abraded bryomol (bryozoan + bivalve mollusc) facies skeletons coated with isopachous rinds of typically nonferroan, dull to blotchy luminescent, fibrous to bladed spar, often with porosity occlusion by detrital and/or precipitated micrite. The limestones are usually thin and rare, of Oligocene - early Miocene age, and are interpreted to have formed by marine cementation at the seafloor under special environmental conditions associated with high energy levels and reduced sedimentation rates.

Class II limestones have open fabrics with meagre amounts of dull to bright luminescent, ferroan to nonferroan, often substrate-specific, bladed to dog-toothed scalenohedral fringe or syntaxial rim cement. These porous, bryomol, echinofor (echinoderm + benthic foraminifera), and less commonly barnamol (barnacle + bivalve mollusc) facies limestones are relatively common, especially in OligoceneMiocene eastern South Island and in some Pliocene eastern Vorth Island occurrences, where diagenesis occurred mainly under conditions of only shallow burial $(<500 \mathrm{~m})$ in the presence of essentially marine pore fluids.

Class III limestones have open to moderately open fabrics with typically nonferroan to ferroan, variably uminescent, fine to coarse drusy equant spar, and often include a range of neomorphosed, formerly aragonitic, bivalve skeletal fabrics. Composed predominantly of barnamol and bimol (bivalve mollusc) facies, these usually rather porous Pliocene-Pleistocene limestones are especially common in eastern North Island, and were characterised by diagenesis initially in the shallow burial realm and subsequently under variable influence from meteoric fluids, both in the subsurface and following uplift.

Class IV limestones are characterised by tight and highly pressure-dissolved fabrics, with scant pore spaces filled by

G95023

Received 24 Mard 1995: accepted 25 September 1995 usually ferroan, dull luminescent, clear drusy equant spar. These hard, flaggy, bryomol-dominated limestones are common, of Oligocene-Miocene (and also PaleoceneEocene) age, and their diagenesis proceeded mainly under conditions of moderate to deep burial $(500-1500 \mathrm{~m})$ in the presence of marine-modified connate fluids.

The spectrum of marine, shallow burial, meteoric, and deep burial spar cements recognised in the New Zealand limestones; together with special diagenetic features such as neomorphosed aragonitic fabrics and polygenetic micrites, remains to be fully appreciated and incorporated into existing models of nontropical shallow-marine carbonate evolution.

Keywords Cenozoic; New Zealand; limestones; calcite; nontropical carbonates; diagenesis; cementation; aragonite

\section{INTRODUCTION}

Shallow-marine carbonates in nontropical settings have several properties that contrast with those in tropical regions, including variations in the nature and extent of the major diagenetic processes experienced and the resultant diagenetic products (Fig. 1; Nelson 1988). While sea water in tropical environments is supersaturated with respect to $\mathrm{CaCO}_{3}$ and

\begin{tabular}{|c|c|}
\hline $\begin{array}{l}\text { TROPICAL SHELF } \\
\text { CARBONATES }\end{array}$ & $\begin{array}{l}\text { NONTROPICAL SHELF } \\
\text { CARBONATES }\end{array}$ \\
\hline $\begin{array}{l}\text { RIMMED SHELF } \\
\text { HIGH TO LOW ENERGY }\end{array}$ & $\begin{array}{l}\text { UNRIMMED SHELF } \\
\text { HIGH ENERGY }\end{array}$ \\
\hline $\begin{array}{l}\text { HERMATYPIC CORAL REEFS } \\
\left(30^{\circ} \mathrm{N} \text { TO } 30^{\circ} \mathrm{S}\right)\end{array}$ & $\begin{array}{l}\text { HERMATYPIC REEFS ABSENT } \\
\text { (BEYOND } 30^{\circ} \mathrm{N} \text { AND S) }\end{array}$ \\
\hline $\begin{array}{l}\text { CHLOROZOAN SKELETAL TYPES } \\
\text { (CORALS, CALC. GREEN ALGAE, } \\
\text { MOLLUSCS, BENTHIC FORAMS) }\end{array}$ & $\begin{array}{l}\text { FORAMOL SKELETAL TYPES } \\
\text { (BRYOZOANS, ECHINODERMS, } \\
\text { BIVALVE MOLLUSCS, FORAMS) }\end{array}$ \\
\hline $\begin{array}{l}\text { SAND AND MUD TEXTURES } \\
\text { DOMINATE }\end{array}$ & $\begin{array}{l}\text { GRAVEL AND SAND TEXTURES } \\
\text { DOMINATE }\end{array}$ \\
\hline $\begin{array}{l}\text { WARM WATER }\left(>20^{\circ} \mathrm{C}\right) \\
\text { SATURATED/SUPERSATURATED }\end{array}$ & $\begin{array}{l}\text { COOL WATER }\left(<20^{\circ} \mathrm{C}\right) \\
\text { SATURATED/UNDERSATURATED }\end{array}$ \\
\hline $\begin{array}{l}\text { NONSKELETAL GRAINS } \\
\text { (OOIDS, AGGREGATES) }\end{array}$ & NONSKELETAL GRAINS ABSENT \\
\hline MARINE AND METEORIC CEMENTS & BURIAL CEMENTS \\
\hline $\begin{array}{l}\text { ARAGONITE AND HIGH-Mg } \\
\text { CALCITE MINERALOGY }\end{array}$ & $\begin{array}{l}\text { LOW-AND MODERATE-Mg } \\
\text { CALCITE MINERALOGY }\end{array}$ \\
\hline CONSTRUCTIVE DIAGENESIS & DESTRUCTIVE DIAGENESIS \\
\hline $\begin{array}{l}\text { TYPICALLY HIGH } \\
\text { ACCUMULATION RATES }\end{array}$ & $\begin{array}{l}\text { TYPICALLY LOW } \\
\text { ACCUMULATION RATES }\end{array}$ \\
\hline
\end{tabular}

Fig. 1 Some contrasting environmental, compositional, anc. diagenetic features of tropical and nontropical shelf carbonate: facies (after Nelson 1988). 


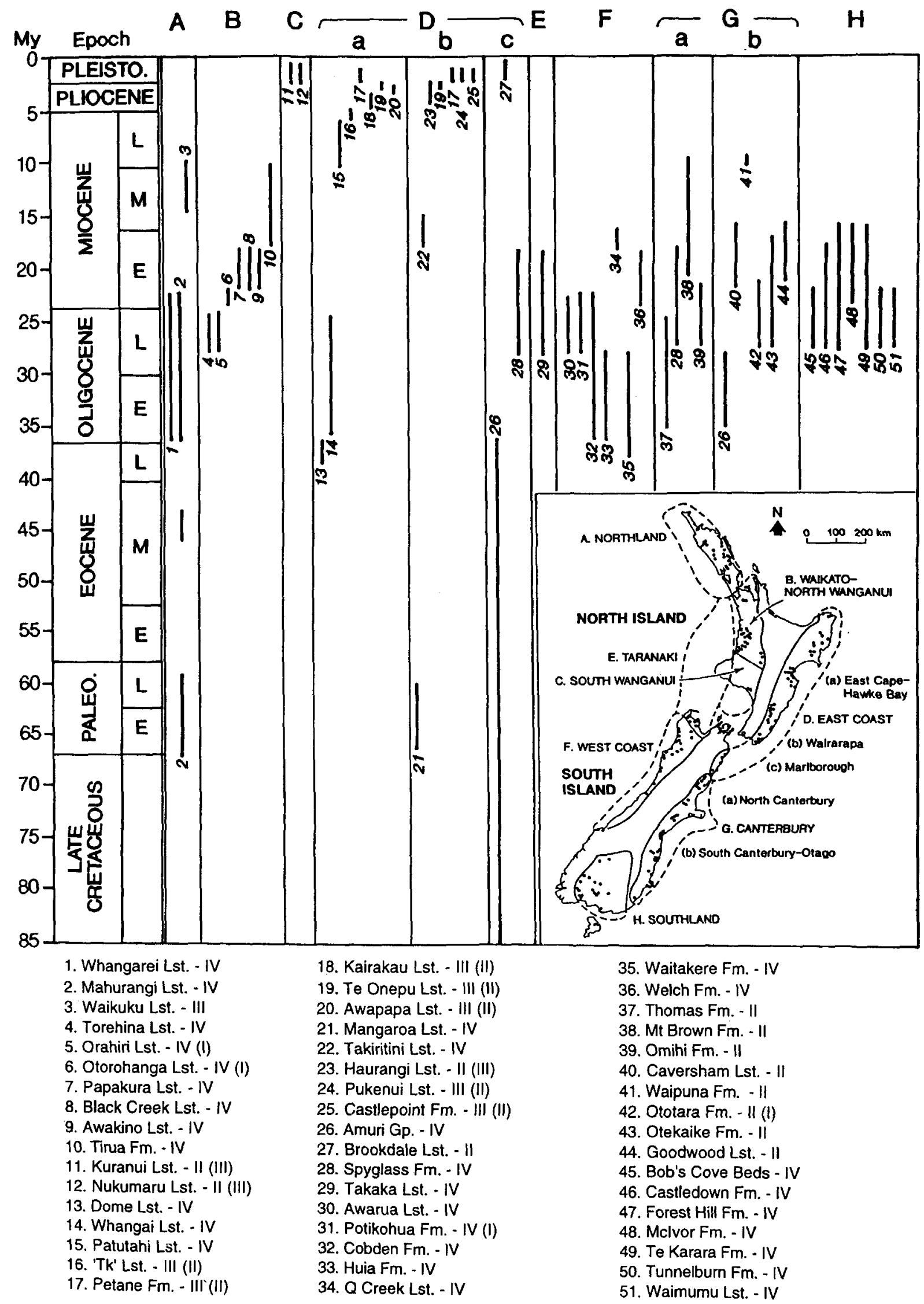

Fig. 2 The age range, distribution, and typical diagenetic class of the main Cenozoic nontropical limestones in New Zealand. The letters at the top of the diagram refer to the Cenozoic sedimentary basins shown in the inset map of New Zealand. The vertical lines indicate approximate age range of the numbered limestone units, defined in the lower key. The roman numeral code to the right of eact lithostratigraphic name defines the dominant diagenetic class (subdominant in brackets) within that limestone. I, seafloor; II, shallow burial; III, combined shallow burial - meteoric; and IV, deep burial (see Fig. 11). 
Fig. 3 A highly idealised New Zealand Cenozoic sedimentary sequence showing the occurrence of three main levels of limestone development, each dominated by characteristic skeletal assemblages (see Fig. 4): PaleoceneEocene Amuri nannofor megafacies, Oligocene-Miocene Te Kuiti bryomol and echinofor megafacies, and PliocenePleistocene Te Aute barnamol and bimol megafacies. G, glauconite,

$\uparrow$, carbonaceous.

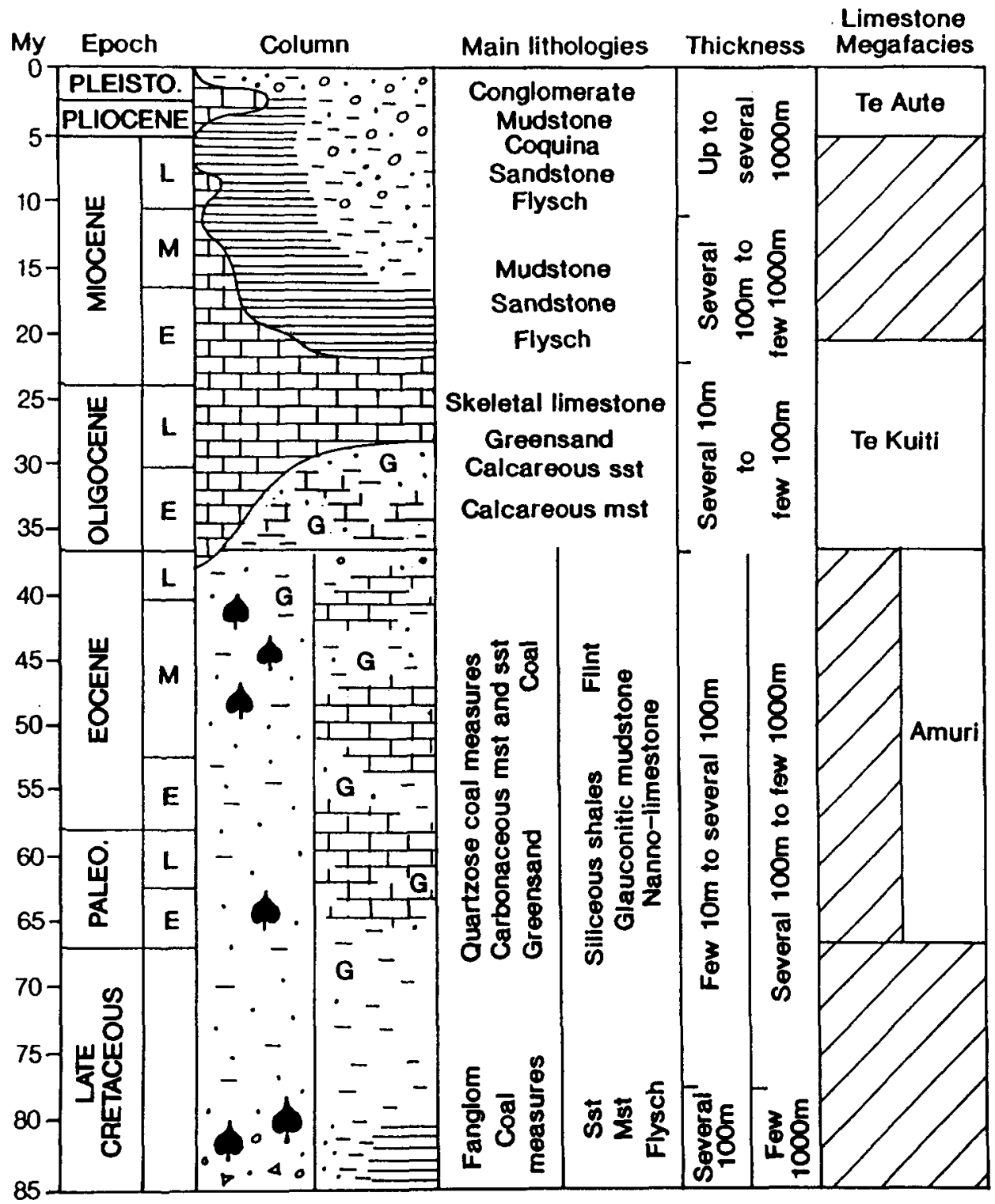

supports abundant and diverse carbonate-secreting crganisms, more temperate environments experience a lesser degree of saturation, and even undersaturation (Alexandersson 1978), and a less diverse flora and fauna (Leonard et al. 1981). The cooler temperatures associated with nontropical waters, their higher $\mathrm{CO}_{2}$ content, and the generally slower rates of carbonate accumulation, encourage destructive early diagenesis by bioerosion, maceration, and selective or total dissolution of metastable skeletons (e.g., Young \& Nelson 1988; Smith \& Nelson 1994). The cooler conditions also discourage or limit direct precipitation of marine cements and other inorganic chemical precipitates, such as ooids and aggregates (Nelson 1988). Thus, in comparison with many tropical carbonates, cementation tends to be delayed until the later stages of diagenesis, where $i$ it is sourced from pressure-dissolution of the carbonate skeletons during burial or, less commonly, from the dissolution or neomorphism of any aragonitic skeletons in the deposits (e.g., Nelson et al. 1988).

Nontropical shallow-marine limestones are widely distributed in New Zealand Cenozoic sequences, especially in the Oligocene - earliest Miocene in both islands, and the Pliocene-Pleistocene in North Island (Fig. 2, 3). A spectrum of limestone types exists, but all are skeletal dominated $(>70 \%)$, with typically $<20 \%$ interparticle cement-matrix and $<10 \%$ siliciclasts (Nelson 1978). Their skeletal makeup involves assemblages characteristic of temperate carbonates (Fig. 4) (Hayton et al. 1995). These limestones formed at paleolatitudes between 60 and $35^{\circ} \mathrm{S}$ (Nelson 1978) under mainly cool-temperate to warm-temperate climatic conditions, marginally subtropical at times. This is generally supported by paleontological evidence (Hornibrook 1992) and by the oxygen isotope record, the latter suggesting mean water temperatures in the New Zealand region since the Eocene were mainly cooler than c. $20^{\circ} \mathrm{C}$ (Nelson 1978).

In this paper, while appreciating the complexity and continuity of diagenetic processes and their often locationspecific nature in detail, we nevertheless recognise and group the broad diagenetic features and histories for most major occurrences of New Zealand Cenozoic shallow-marine limestones (Fig. 2), as a contribution towards developing 


\begin{tabular}{|c|c|c|}
\hline $\begin{array}{c}\text { Skeletal } \\
\text { assemblage }\end{array}$ & $\begin{array}{l}\text { Major skeletal } \\
\text { components }\end{array}$ & $\begin{array}{c}\text { Typical primary } \\
\text { mineralogy }\end{array}$ \\
\hline Bryomol & $\begin{array}{c}\text { Bryozoans } \\
\text { (Bivalve molluscs) } \\
\text { (Echinoderms) } \\
\text { (Benthic foraminifera) }\end{array}$ & $\begin{array}{l}\text { MMC-LMC } \\
(\text { LMC) } \\
\text { (HMC) } \\
\text { (MMC) }\end{array}$ \\
\hline Echinofor & $\begin{array}{c}\text { Echinoderms } \\
\text { Benthic foraminifera } \\
\text { (Bryozoans) } \\
\text { (Planktic foraminifera) }\end{array}$ & $\begin{array}{c}\text { HMC } \\
\text { MMC } \\
(\mathrm{MMC}-\mathrm{LMC}) \\
(\mathrm{LMC})\end{array}$ \\
\hline Nannofor & $\begin{array}{c}\text { Nannofossils } \\
\text { Planktic foraminifera }\end{array}$ & $\begin{array}{l}\text { LMC } \\
\text { LMC }\end{array}$ \\
\hline Barnamol & $\begin{array}{c}\text { Barnacles } \\
\text { Bivalve molluscs } \\
\text { (Bryozoans) } \\
\text { (Echinoderms) }\end{array}$ & $\begin{array}{c}\text { LMC } \\
\text { LMC/Arag } \\
(\mathrm{MMC}-\mathrm{LMC}) \\
(\mathrm{HMC})\end{array}$ \\
\hline Rhodechfor & $\begin{array}{c}\text { Calcareous red algae } \\
\text { Benthic foraminifera } \\
\text { (Echinoderms) } \\
\text { (Bryozoans) }\end{array}$ & $\begin{array}{c}\text { HMC } \\
\text { MMC } \\
(\text { HMC) } \\
\text { (MMC-LMC) }\end{array}$ \\
\hline Bimol & $\begin{array}{c}\text { Bivalve molluscs } \\
\text { (Barnacles) } \\
\text { (Bryozoans) } \\
\text { (Benthic foraminifera) }\end{array}$ & $\begin{array}{c}\text { Arag/LMC } \\
\text { (LMC) } \\
(\mathrm{MMC}-\mathrm{LMC}) \\
(\mathrm{MMC})\end{array}$ \\
\hline Rhodoalgal & $\begin{array}{c}\text { Calcareous red algae } \\
\text { (Benthic foraminifera) } \\
\text { (Bryozoans) } \\
\text { (Echinoderms) }\end{array}$ & $\begin{array}{c}\text { HMC } \\
(\mathrm{MMC}) \\
(\mathrm{MMC}-\mathrm{LMC}) \\
(\mathrm{HMC})\end{array}$ \\
\hline
\end{tabular}

Fig. 4 Skeletal assemblage types in New Zealand Cenozoic limestones (from Hayton et al. 1995), their main skeletal components, and typical primary mineralogy. LMC, low-Mg calcite (<4 mol.\% $\mathrm{MgCO}_{3}$ ): $\mathrm{MMC}$, moderate-Mg calcite (4-10 mol. \% $\mathrm{MgCO}_{3}$ ); $\mathrm{HMC}$, high-Mg calcite (>10 mol.\% $\mathrm{MgCO}_{3}$ ); Arag, aragonite. () denotes less common.

diagenetic scenarios for nontropical carbonate deposits more generally. The database for the synthesis comes largely from unpublished theses lodged in New Zealand universities, especially those of Nelson (1973), Hood (1993), and Hayton (1995), but also Hyden (1979), Leask (1980), Dobbie (1982), Anderson (1984), Harmsen (1984, 1985), Harris (1986), Lawrence (1989), and Haywick (1990), and includes field observations, information from standard, stained and cathodoluminescence (CL) petrography, and from scanning electron microscopy, and the results of X-ray diffraction and limited geochemical analysis of samples.

\section{DIAGENETIC CLASSES}

The nature and abundance of the different diagenetic features preserved in the New Zealand Cenozoic limestones form the basis for grouping the limestones into four diagenct classes (Fig. 5). The geographic and age distribution of thes classes (Fig. 2) is summarised in Fig. 6 and 7, respectivel

\section{Class I}

Class I limestones are of Oligocene-Miocene age and a/ 3 generally relatively massive, coarse calcarenites to fir : calcirudites that have very open fabrics and few chemic $t$ compactional features, such as (micro)stylolites. Skeletil grains are characteristically broken, moderately to strongly abraded, well sorted, and are dominated by the bryom,l skeletal assemblage (Fig. 4). The limestones are both biomicrites and biosparites.

Petrographically, the limestones are characterised by the occurrence of first generation inter- and intra-particle isopachous spar rinds, typically $50-200 \mu \mathrm{m}$ thick (Fig. $8 \mathrm{~A}$ ) (Nelson \& James 1995). These cements are clear to dusty (inclusion rich) in appearance, have a variety of acicular to fibrous habits, and although now low-Mg calcite (LMC; <4 mol.\% $\mathrm{MgCO}_{3}$ ), were possibly precipitated as metastable $\mathrm{Mg}$ calcite, judging from their relatively enriched $\mathrm{Mg}$ content compared to other components (Nelson \& James 1995). Tlo cements are nonferroan and usually exhibit a non to dull ir blotchy CL. The common retention of large depositional interparticle pore volumes (up to $45 \%$ ) is particularly characteristic. Porewards of the isopachous spar rinds, any remaining pore spaces are filled by micrite and/or spar. ir rarely remain empty. The micrite can have microbioclasti: homogeneous, or peloidal fabrics (Nelson \& James 1995, whereas the spar is clear, mainly ferroan equant calcite $\mathrm{with}$ dull CL. Evidence of former aragonitic components is a feature of the Class I limestones, either as spar-filled biomoulds (Fig. 8A) or skeletons neomorphosed to LMC

\section{Class II}

Class II limestones are calcarenites to fine calcirudites of mainly Oligocene-Miocene age, but include some of Pliocene age, that are relatively soft, friable, poorly and often differentially cemented biosparites, rarely biomicrite, dominated by the bryomol and echinofor, and less commonly barnamol skeletal assemblages (Fig. 4). An overall paucily of cement is characteristic (Fig. 8B), but where present it typically occurs as thin, sporadic, uneven spar fringes. The fringes often appear to be best developed upon specifio substrates, especially as syntaxial rim spar about echinoderm fragments and/or as bladed to dog-toothed spar about certain bivalves. The syntaxial spar is nonferroan or ferroan and may exhibit a non-bright-dull concentric CL zonation. T.e limestones mainly have open to moderately open fabrics with only occasional evidence for the initiation of mild pressur:dissolution effects at grain contacts. Rare examples occur of spar-filled biomoulds of former aragonitic skeletons

\section{Class III}

These "Te Aute megafacies" limestones (Fig. 3), of Pliocene-Pleistocene age, are commonly differentially cemented at a range of outcrop scales, varying from dense, well-cemented biosparites, to soft and friable, poorly cemented rocks. They are dominantly coarse calcirudites, sometimes coquinites (whole shells), with generally op n to moderately open fabrics. Their content of terrigenous material may range up to $40 \%$. The limestones are dominated by barnamol and bimol skeletal assemblages, with some 


\begin{tabular}{|c|c|c|c|c|c|c|c|c|c|c|c|c|}
\hline \multirow{3}{*}{ Diagenetic process(es) } & \multirow{3}{*}{ Diagenetic feature(s) } & \multicolumn{11}{|c|}{ Diagenetic class } \\
\hline & & \multicolumn{2}{|c|}{\begin{tabular}{|c|}
\multicolumn{2}{|c|}{ I } \\
\end{tabular}} & \multicolumn{3}{|c|}{ II } & \multicolumn{3}{|c|}{ III } & \multicolumn{3}{|c|}{ IV } \\
\hline & & \begin{tabular}{|l|} 
None L Low \\
\end{tabular} & $\begin{array}{ll}\text { Mod } & \text { High } \\
\end{array}$ & None Low & Mod & High & None Low & Mod & High & None Low & Mod & High \\
\hline \multirow{3}{*}{$\begin{array}{l}\text { Mechanical, biological, } \\
\text { and chemical erosion }\end{array}$} & Skeletal abrasion & & 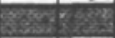 & & & & & & & & & \\
\hline & Skeletal bioerosion & & & & & & & & & & & \\
\hline & Seafloor skeletal dissolution & & & & & & & & & & & \\
\hline \multirow{2}{*}{$\begin{array}{l}\text { Physical } \\
\text { compaction }\end{array}$} & Skeletal grain fracture/ realignment & & & & & & & & & & & \\
\hline & Rock fractures and veins & & & & & & & & & & & \\
\hline \multirow{2}{*}{$\begin{array}{l}\text { Chemical } \\
\text { compaction }\end{array}$} & Pressure-dissolution contacts & & & & & & & & & & & \\
\hline & Stylolitic seams & & & & 羉 & & 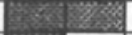 & & & & $\mathrm{x}$ & 璭 \\
\hline \multirow{5}{*}{ Cementation } & Fibrous-bladed isopachous spar rinds & & & & & & & & & & & \\
\hline & Micrite (cement and/or matrix) & & & & & & & & & & & \\
\hline & Syntaxial rim spar & & & & & & & & & &  & \\
\hline & Bladed/dog-tooth spar (substrate specific) & & & & & & & & & & 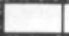 & \\
\hline & Equant (micro-) spar & & & & & & & & & & & \\
\hline \multirow{6}{*}{$\begin{array}{l}\text { Neomorphism } \\
\text { and } \\
\text { dissolution }\end{array}$} & Micrite envelopes & & & & & & & & & & & \\
\hline & Thin-film transformation & & & & & & & & & & & \\
\hline & Incongruent dissolution & & & & & & & & & & 䠄 & \\
\hline & Dissolution/reprecipitation & & & & & & & & & & & \\
\hline & Biomould formation & & & & & & & & & & & \\
\hline & Micrite to microspar & & & & & & & & & & & \\
\hline \multirow{4}{*}{$\begin{array}{l}\text { Non-carbonate } \\
\text { authigenesis }\end{array}$} & Pyrite & & & & & & & & & & 25 & \\
\hline & Glauconite & & & & & & & & & & 玹 & \\
\hline & Phosphatic minerals & & & & & & & & & & & \\
\hline & Iron/manganese minerals & . & & & & & & & & & & \\
\hline
\end{tabular}

Fig. 5 The nature and relative occurrence of diagenetic processes and features in the diagenetic classes established for New Zealand Cenozoic limestones. The value of individual processes/features relates to the maximum of the shaded bar (e.g., occurrence of skeletal abrasion in Class I is high, occurrence of skeletal bioerosion in Class I is low). Based mainly on data from Nelson (1973), Hood (1993), and Hayton (1995).

\begin{tabular}{|c|c|c|c|c|}
\hline \multirow{2}{*}{$\begin{array}{l}\text { New Zealand } \\
\text { sedimentary basin }\end{array}$} & \multicolumn{4}{|c|}{ Diagenetic class } \\
\hline & I & II & III & IV \\
\hline \multicolumn{5}{|l|}{ Northland } \\
\hline \multicolumn{5}{|c|}{ Waikato-North Wanganui } \\
\hline \multicolumn{5}{|l|}{ South Wanganui } \\
\hline \multicolumn{5}{|l|}{ East Cape-Hawke Bay } \\
\hline \multicolumn{5}{|l|}{ Wairarapa } \\
\hline \multicolumn{5}{|l|}{ Marlborough } \\
\hline \multicolumn{5}{|l|}{ West Coast } \\
\hline \multicolumn{5}{|l|}{ Canterbury } \\
\hline Southland & & & & \\
\hline
\end{tabular}

Fig. 6 Generalised distribution of limestone diagenetic classes in relation to the various New Zealand Cenozoic sedimentary basins (see inset of Fig. 2). Stipple = present; white = generally absent or rare.

bryomol occurrences (Fig. 4). They are characterised by the presence of locally abundant aragonitic infaunal bivalves, either directly as skeletons, or indirectly as biomoulds and neomorphosed skeletons (Fig. 8C). A special feature in outcrop can be the development of secondary mouldic porosity resulting from variable dissolution of the infaunal bivalve shell components.

Thin-sections show that the mode of aragonite stabilisation varies and involves any of thin-film transformation, dissolution-reprecipitation, or complete dissolution and empty mould production (Scoffin 1987; Haywick 1990; Maliva \& Dickson 1992; Saller 1992; Hood 1993). Micrite envelopes often surround biomoulds which are variably infilled by nonferroan equant calcite spar (Fig. 8D). A variety of interparticle cement fabrics is evident, and these are often substrate specific. Isopachous bladed to dogtoothed spar cements, most commonly developed about

\begin{tabular}{|c|c|c|c|c|}
\hline \multirow[b]{2}{*}{ Age } & \multicolumn{4}{|c|}{ Diagenetic class } \\
\hline & I & II & III & IV \\
\hline \multicolumn{5}{|l|}{ Pleistocene } \\
\hline \multicolumn{5}{|l|}{ Pliocene } \\
\hline \multicolumn{5}{|l|}{ Miocene } \\
\hline \multicolumn{5}{|l|}{ Oligocene } \\
\hline \multicolumn{5}{|l|}{ Eocene } \\
\hline Paleocene & & & & \\
\hline
\end{tabular}

Fig. 7 Generalised age distribution of diagenetic classes within New Zealand Cenozoic limestones. Stipple $=$ present; white $=$ absent or rare.

originally aragonitic bivalves, are the characteristic first generation cement (Fig. 8C, D). These cements less commonly have fibrous to acicular habits that are restricted to originally aragonitic skeletons. Syntaxial rim spar about echinoderms is common and may be poorly to very well developed. The dominant pore-occluding cement is equant calcitic spar (Fig. 8D), usually nonferroan but occasionally ferroan, with a generally dull to non $\mathrm{CL}$, although rare multiple concentric zonations with bright CL may also be present.

\section{Class IV}

Class IV limestones, especially widespread in OligoceneMiocene sections, are dominantly biosparites with lesser biomicrites. They are typically coarse calcarenites to fine calcirudites dominated by the bryomol skeletal assemblage, but also including echinofor and rhodechfor assemblages 

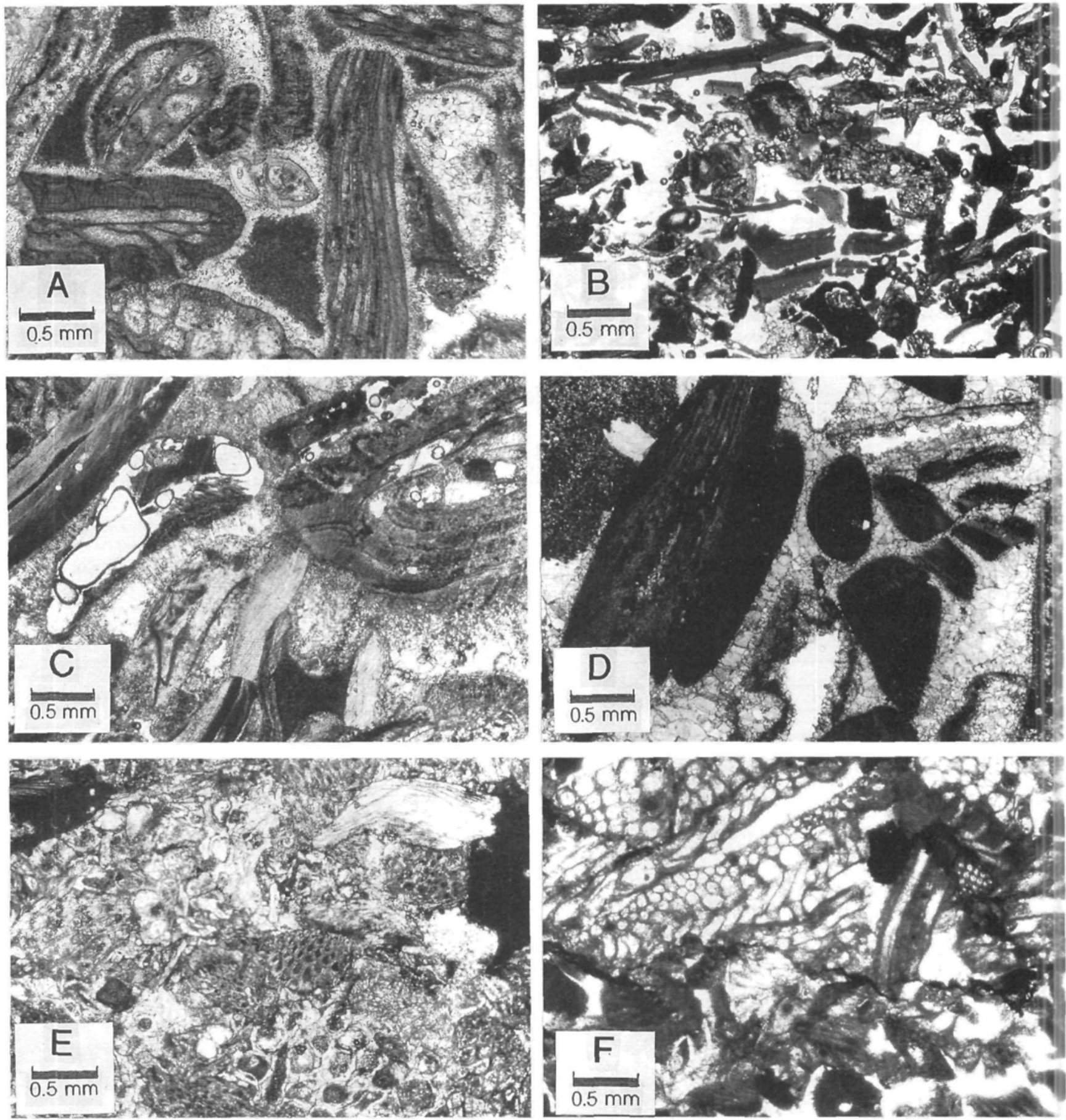

Fig. 8A-F Thin-section photomicrographs, in plane-polarised light, representative of the four diagenetic classes identified within New Zealand Cenozoic limestones where, $\mathrm{A}=$ Class I (seafloor); $\mathrm{B}=$ Class II (shallow burial); $\mathrm{C}, \mathrm{D}=\mathrm{Class}$ III (combined shallow burial - meteoric; and E. F = Class IV (deep burial). A, Open fabric coarse calcarenite, composed predominantly of bryozoan grains First-generation fibrous cement is dusty inclusion-rich nonferroan isopachous spar with remaining interparticle porosity occluded by micrite or equant spar. Spar-filled micrite envelopes (top left and far right) are evidence for the former existence of originally aragonitic bivalves. Sample 16927, Orahiri Limestone. North Wanganui. B. Very open fabric calcarenite composed of echinoderm, bryozoan. and bivalve fragments, with a paucity of cement limited to irregular equant LMC spar fringes about some grains, and poorly developed syntaxial rims about echinoderm grains. Sample W94653. Ototara Formation. Canterbury. C. Moderately open fabric calcirudite to coquinite, composed predominantly of barnacle plates and bivalve fragments (both originally calcitic and aragonitic). An aragonitic bivalve fragment (left centre) has been incompletely dissolved with some of the original mineralogy (plus thin-section bubbles) remaining Skeletal grains are coated by either a dusty inclusion-rich uneven fibrous first generation spar (originally ?aragonitic, now LMC) or dirty even spar rind (originally calcitic grains). Final porosity occlusion is by nonferroan equant LMC. Sample W93351. Te Onepu Limestone, East Cape - Hawke Bay. D. Moderately open fabric fine calcirudite composed predominantly of barnacle plates. bivalv fragments (originally calcitic and aragonitic), and bryozoan fragments. First generation uneven equant - dog-toothed LMC spar followed by often coarse nonferroan equant-drusy LMC. Aragonitic bivalves have been dissolved. leaving micrite envelopes and secondar mouldic pores which have subsequently been partially infilled by nonferroan equant LMC, or have been neomorphically stabilised to nonferroan LMC. Sample W93344, Park Island Limestone (= Petane Formation). East Cape-Hawke Bay. E. Tight pressure-dissolved > 


\begin{tabular}{|c|c|c|c|c|c|c|c|c|c|c|c|c|c|c|c|c|c|}
\hline \multirow{3}{*}{$\begin{array}{c}\text { Broad } \\
\text { diagenetic controls }\end{array}$} & \multirow{3}{*}{$\begin{array}{c}\text { Specific } \\
\text { diagenetic controls }\end{array}$} & \multicolumn{16}{|c|}{ Diagenetic class } \\
\hline & & \multicolumn{4}{|c|}{$\mathbf{I}$} & \multicolumn{4}{|c|}{ II } & \multicolumn{4}{|c|}{ III } & \multicolumn{4}{|c|}{ IV } \\
\hline & & \begin{tabular}{|l|} 
None \\
\end{tabular} & Low & Mod & High & None & Low & Mod & High & None & Low & Mod & High & None & Low & Mod & High \\
\hline \multirow{7}{*}{ Sedimentary } & Skeletal composition & & & & & & & & & & & & & & & & \\
\hline & Skeletal mineralogy and stability & & & & & & & & & & & & & & & & \\
\hline & Grain size & & & & & & & & & & & & & & & & \\
\hline & Porosity and permeability & & & & & & & & & & & & & & & & \\
\hline & Texture & & & & & & & & & & & & & & & & \\
\hline & Rate of sedimentation & & & & & & & & & & & & & & & & \\
\hline & Terrigenous input & & & & & & & & & & & & & & & & \\
\hline \multirow{7}{*}{ Tectonic } & Burial depth & & & & & & & & & & & & & & & & \\
\hline & Time of burial & & & & & & & & & & & & & & & & \\
\hline & Eustatic sea-level fluctuations & & & & & & & & & & & & & & & & \\
\hline & General submergence event & & & & & & & & & & & & & & & & \\
\hline & General emergence event & & & & & & & & & & & & & & & & \\
\hline & Dip of strata & & & & & & & & & & & & & & & & \\
\hline & Terrigenous input & & & & & & & & & & & & & & & & \\
\hline \multirow{10}{*}{$\begin{array}{c}\text { General } \\
\text { environmental } \\
\text { conditions }\end{array}$} & Latitude & & & & & & & & & & & & & & & & \\
\hline & Upwelling & & & & & & & & & & & & & & & & \\
\hline & Seawater flux & & & & & & & & & & & & & & & & \\
\hline & Water depth at deposition & & & & & & & & & & ma & 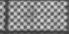 & & & & & \\
\hline & Environmental energy at deposition & & & & & & & & & & . & & & & & & \\
\hline & Pore fluid chemistry & & & & & & & & & & & & & & & & \\
\hline & Pore fluid residency time & & & & & & & & & & & & & & & & \\
\hline & Temperature of seawater & & & & & & & & & & & & & & & & \\
\hline & Eh conditions & & & & & & & & & & & & & & & & \\
\hline & Substrate type & & & 苾 & & & : & & & & $3 x$ & & & & & & \\
\hline
\end{tabular}

Fig. 9 Relative importance of the principal diagenetic controls for each of the diagenetic classes of New Zealand Cenozoic limestones. The value of individual processes/features relates to the maximum of the shaded bar (e.g., relative importance of skeletal composition in Class I is moderate, relative importance of grain size in Class II is none).

(Fig. 4). Stylolites and dissolution seams are prominent features in the limestones, along which preferential weathering occurs to produce a characteristic flaggy appearance in outcrop. These limestones are typically hard, crystalline, and very well cemented.

Petrographically, these limestones exhibit tight pressuredissolved fabrics and substantially reduced intergranular pore volumes, typically $10-15 \%$ or less (Fig. 8E, F). First generation cements are generally substrate specific and form uneven fringes of bladed to dog-toothed spar. Syntaxial rim spar cements about echinoderms are characteristically well developed and may change outwards from nonferroan to ferroan and exhibit a typical burial CL sequence of nonbright-dull-bright-dull zones (Nelson et al. 1988). The bulk of the pore-occluding cement is clear, dominantly ferroan, often drusy, equant spar, with a characteristically dull CL. Skeletal grain fracture is common, and grain-to-grain contacts are (highly) pressure dissolved, often being sutured or concavo-convex, and microstylolites are common (Fig. $8 \mathrm{E}, \mathrm{F})$. Any evidence of former aragonitic skeletons from micrite envelopes or spar-filled biomoulds is extremely rare.

A special subclass of the Class IV limestones are finegrained limestones (micrites or calcilutites) composed of the nannofor skeletal assemblage (Fig. 4). These "Amuri megafacies" limestones (Fig. 3) of mainly Paleogene age consist of planktic foraminifera set in a micrite matrix dominated by calcareous nannofossil material (e.g., Nelson 1968; Carter 1969; Lewis 1992). They typically have tight pressure-dissolved fabrics with common stylolites (Lewis 1992). Cements are dominated by microspar, and authigenic pyrite is common.

\section{DIAGENETIC ENVIRONMENTS AND PATHWAYS}

The diagenesis of New Zealand limestones has been controlled by a combination of different temperate-latitude depositional settings, by basinal tectonic histories, by the degree of influence of eustatic sea-level fluctuations, by the composition and degree of preservation of the original metastable skeletons, by the chemistry of the pore fluids, and by the period of residency of these pore fluids (Fig. 9). Together these factors have been responsible for the evolution of four recurring and contrasting diagenetic classes. By considering the wide range of diagenetic features typical of each of the diagenetic classes it is possible to relate them to different diagenetic environments and to suggest pathways along which the New Zealand limestones (classes for individual limestones are shown in Fig. 2) have evolved

fabric calcarenite composed mainly of bryozoan and some bivalve and echinoderm fragments. Skeletal grain dissolution along microstylolitic contacts promotes low interparticle porosity. Rare internal micrite infills have neomorphically aggraded to microspar. First generation interparticle cements are syntaxial rim spar about echinoderm grains with later porosity occlusion by fine, typically ferroan equant LMC. Sample W94626, Takaka Limestone, South Taranaki. F, Tight pressure-dissolved fabric with microstylolitic grain contacts and little remaining interparticle porosity. Skeletal grains are dominated by bryozoans, with lesser amounts of echinoderm and benthic foraminifera fragments. An irregular stylolite seam traverses the centre of the field, with a concentration of insoluble residues. Sample W94576, Potikohua Formation, West Coast. 


\begin{tabular}{|c|c|c|c|c|c|c|c|c|c|c|c|c|c|c|c|}
\hline \multirow{3}{*}{$\begin{array}{c}\text { Diagenetic } \\
\text { class }\end{array}$} & \multirow{3}{*}{$\begin{array}{l}\text { Dominant } \\
\text { diagenetic } \\
\text { environment }\end{array}$} & \multirow{3}{*}{$\begin{array}{l}\text { Secondary } \\
\text { diagenetic } \\
\text { environment }\end{array}$} & \multirow{3}{*}{$\begin{array}{l}\text { Dominant } \\
\text { original } \\
\text { skeletal } \\
\text { mineralogy }\end{array}$} & \multirow{3}{*}{$\begin{array}{l}\text { Mode(s) of } \\
\text { skeletal } \\
\text { diagenesis }\end{array}$} & \multirow{3}{*}{$\begin{array}{c}\text { Diagenetic } \\
\text { skeletal } \\
\text { mineralogy(s) }\end{array}$} & \multicolumn{6}{|c|}{ Cemenumatrix characteristics } & \multirow{2}{*}{\multicolumn{4}{|c|}{$\begin{array}{c}\text { General limestone } \\
\text { characteristics }\end{array}$}} \\
\hline & & & & & & \multicolumn{5}{|c|}{ Spsrite cements } & \multirow{2}{*}{$\begin{array}{l}\text { Micrite } \\
\text { cement/ } \\
\text { matrix } \\
\end{array}$} & & & & \\
\hline & & & & & & $\begin{array}{l}\text { Cement } \\
\text { source(s) }\end{array}$ & $\begin{array}{l}\text { Cement } \\
\text { Cabric(s) }\end{array}$ & $\begin{array}{c}\mathrm{C} 2 \mathrm{CO} 3 \\
\text { mineralogy }\end{array}$ & $\begin{array}{c}\mathrm{Fe} \\
\text { content }\end{array}$ & $\begin{array}{c}\text { CL } \\
\text { signature }\end{array}$ & & $\begin{array}{c}\text { Rock } \\
\text { classification }\end{array}$ & \begin{tabular}{|c|} 
Rock \\
texture \\
\end{tabular} & $\begin{array}{c}\text { Grain } \\
\text { packing }\end{array}$ & $\begin{array}{l}\text { Other dingenetic } \\
\text { features }\end{array}$ \\
\hline 1 & $\begin{array}{l}\text { seanloor } \\
\text { (uppermost } \\
\text { fur } \mathrm{m} \text { ) }\end{array}$ & shallow burial & $\begin{array}{c}\text { MMC-LMC } \\
\text { >aragonitc } \\
\text { LMC } \\
\text { LMC }\end{array}$ & 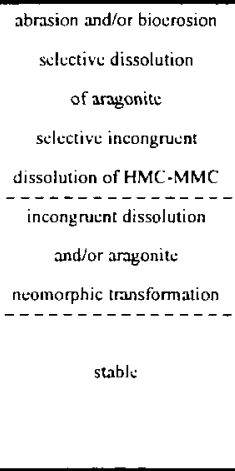 &  & $\begin{array}{c}\begin{array}{c}\text { direct } \\
\text { marinc } \\
\text { precipitation }\end{array} \\
\text { mild pressure-dissolution } \\
\text { with some } \\
\text { angonitte ncomophism } \\
\text { regional } \\
\text { from } \\
\text { pressure-dissolution }\end{array}$ & $\begin{array}{c}\text { (multiple } \\
\text { generation) } \\
\text { isopachous sinds } \\
\text { of dusty-clear } \\
\text { fibrous-bladed spar } \\
\text { syntaxial rim } \\
\text { rare spar biomoulds } \\
\text { (micrite cnvclopes) } \\
\text { (drusy) } \\
\text { equant } \\
\text { spar }\end{array}$ & $\begin{array}{c}\text { HMC or } \\
\text { MMC } \\
\text { now } \\
\text { LMC }\end{array}$ & $\begin{array}{l}\text { nonferroan } \\
\text { nonferroan } \\
\text { to } \\
\text { ferroan } \\
\text { ferroan }\end{array}$ & $\begin{array}{l}\text { dult } \\
\text { (rarely non } \\
\text { or blotchy) }\end{array}$ & $\begin{array}{c}\begin{array}{c}\text { microbioclastic, } \\
\text { homogentous. } \\
\text { and } \\
\text { peloidal }\end{array} \\
\text { as above } \\
\text { as above }\end{array}$ & $\begin{array}{c}\text { high } \\
\text { cnergy } \\
\text { biomicrites } \\
\text { and } \\
\text { biosparites }\end{array}$ & \begin{tabular}{|c|} 
coarss \\
arrenites \\
and \\
rudites
\end{tabular} & $\begin{array}{l}\text { very } \\
\text { open } \\
\text { to } \\
\text { open }\end{array}$ & $\begin{array}{c}\text { hardground } \\
\text { developmint } \\
\text { phosphatisation } \\
\text { Fu. Mn precipitales } \\
\text { micrite envelopus } \\
\text { preserved } \\
\text { depositional } \\
\text { fabrics } \\
\text { micrite to } \\
\text { microspar }\end{array}$ \\
\hline$\|$ & $\begin{array}{c}\text { shallow burial } \\
\text { (up to } \\
\text { l(t) of } \mathrm{m} \text { ) }\end{array}$ & & $\begin{array}{c}\text { MMC-LMC } \\
+ \\
\text { minor-common } \\
\text { aragonite }\end{array}$ & $\begin{array}{l}\text { incongruent dissolution } \\
\text { and/or } \\
\text { necomorphic transformation }\end{array}$ & $\begin{array}{c}\text { LMC } \\
+ \\
\text { variable } \\
\text { aragonite }\end{array}$ & $\begin{array}{l}\text { mild pressure-dissolution } \\
\text { and/or } \\
\text { aragonitc neomorphism }\end{array}$ & $\begin{array}{l}\text { bladed dog-tooth } \\
\text { spar } \\
\text { rarc } \\
\text { acicular/fibrous } \\
\text { syntaxial rim }\end{array}$ & $\begin{array}{c}\text { LMC } \\
\text { ?angonitc } \\
\text { now LMC } \\
\text { LMC }\end{array}$ & $\begin{array}{l}\text { nonferroan } \\
\text { to } \\
\text { ferroan }\end{array}$ & $\begin{array}{c}\text { "mainly } \\
\text { dull }\end{array}$ & "as above & $\begin{array}{c}\text { biosparites } \\
\gg> \\
\text { biomicrites }\end{array}$ & $\begin{array}{c}\text { arenites } \\
> \\
\text { rudites }\end{array}$ & open & $\begin{array}{c}\text { micrite to } \\
\text { microspar } \\
\text { mild pressure- } \\
\text { dissolution } \\
\text { authigenic minerals } \\
\text { limonite staining } \\
\end{array}$ \\
\hline III & meteoric & & $\begin{array}{c}\text { LMC } \\
>\text { or }= \\
\text { angonite }\end{array}$ & $\begin{array}{l}\text { thin-film } \\
\text { transformation } \\
\text { and/or } \\
\text { dissolution of } \\
\text { aragonite }\end{array}$ & $\begin{array}{c}\text { LMC } \\
+ \\
\text { some aragonite }\end{array}$ & $\begin{array}{c}\text { dominantly } \\
\text { aragonite dissolution } \\
\text { and/or } \\
\text { mild pressure-dissolution }\end{array}$ & $\begin{array}{l}\text { spar biomoulds } \\
\text { (drusy) } \\
\text { equant spar }\end{array}$ & LMC & $\begin{array}{l}\text { dominantly } \\
\text { nonfurroan }\end{array}$ & $\begin{array}{l}\text { generally dull } \\
\text { may be } \\
\text { bright multiple } \\
\text { concentric bands }\end{array}$ & - as above & $\begin{array}{c}\text { biosparites } \\
\gg> \\
\text { biomicrites }\end{array}$ & $\begin{array}{c}\text { rudites } \\
> \\
\text { arenites }\end{array}$ & $\begin{array}{c}\text { open } \\
\text { to } \\
\text { moderately } \\
\text { open }\end{array}$ & $\begin{array}{l}\text { micrite to } \\
\text { microspar } \\
\text { limonite staining } \\
\text { mouldic porosity } \\
\text { micrite envelopes }\end{array}$ \\
\hline IV & $\begin{array}{l}\text { deep burial } \\
(2(1)- \\
(10(1)+\mathrm{m})\end{array}$ & & MMC-LMC & $\begin{array}{l}\text { incongrucunt } \\
\text { dissolution } \\
\text { and } \\
\text { stable }\end{array}$ & LMC & $\begin{array}{l}\text { extrnsive } \\
\text { pressure- } \\
\text { dissolution }\end{array}$ & $\begin{array}{c}\text { finte to coarse } \\
\text { (drusy) equant } \\
\text { spar }\end{array}$ & LMC & $\begin{array}{c}\text { ferroan } \\
\gg \\
\text { nonferroan }\end{array}$ & $\begin{array}{l}\text { dominantly dull } \\
\text { with typical } \\
\text { non, bright, dull, } \\
\text { bright, dull } \\
\text { burial sequence } \\
\text { developed in } \\
\text { syntaxial rims }\end{array}$ & - as above &  & $\begin{array}{l}\text { arrenites } \\
>\text { rudites }\end{array}$ & $\begin{array}{l}\text { tight } \\
\text { pressure- } \\
\text { dissolved }\end{array}$ & $\begin{array}{l}\text { advanoed pressurc- } \\
\text { dissolution } \\
\text { flagginess } \\
\text { styilititus } \\
\text { authigenic minerals } \\
\text { (micrite to microspar) }\end{array}$ \\
\hline
\end{tabular}

NB. Class III lisnestones are generated in the marine environment (Class II) and progress into the meteoric environment in which their characteristic diagenetic features are produced. * Mainly bioclastic micrite


HMC, high-Mg calcite. CL, cathodoluminescence. 
Fig. 11 Summary of diagenetic pathways, classes, and environments for New Zealand Cenozoic limestones.

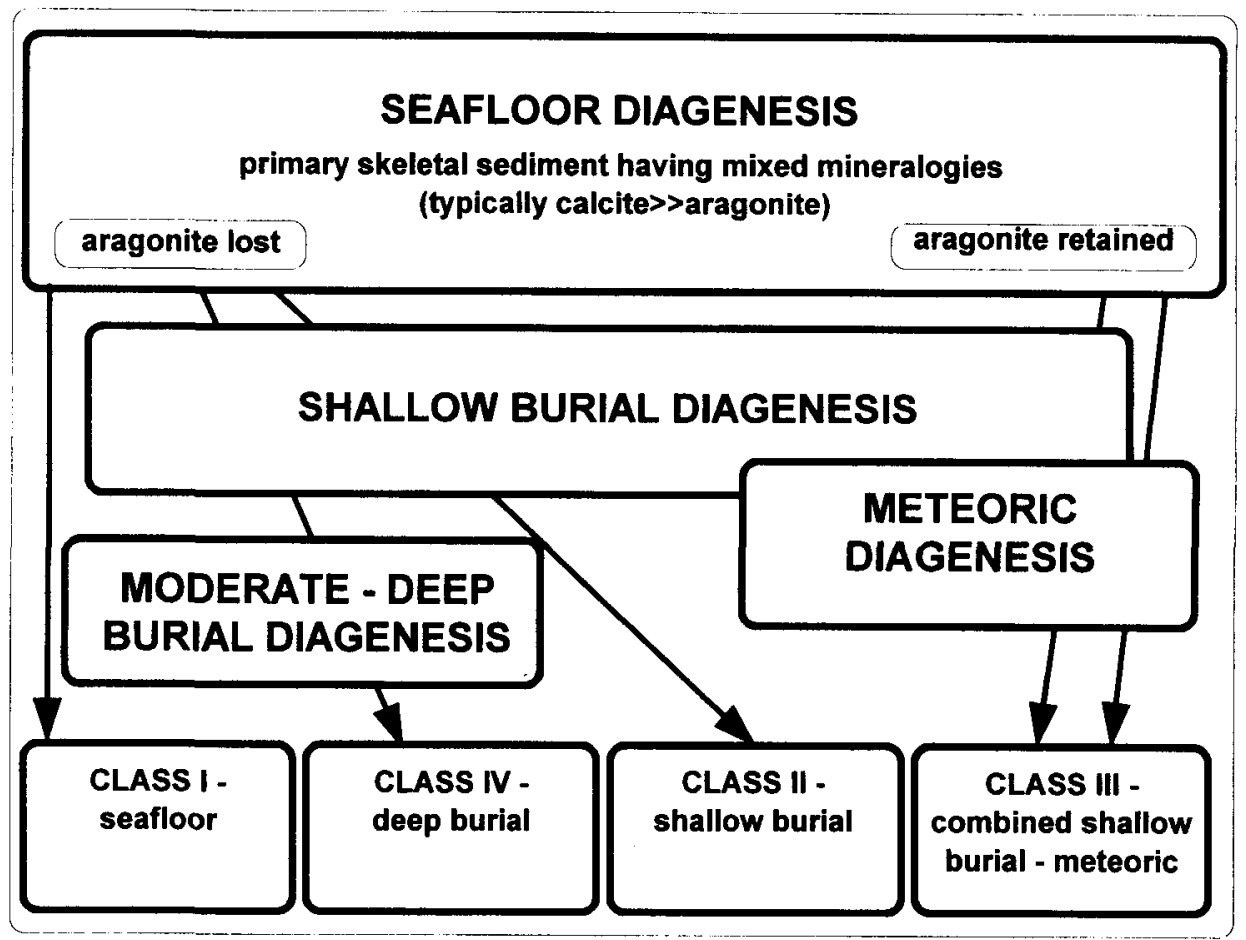

Fig. 10,11). The dominant diagenetic environmental motif issociated with each diagenetic class is interpreted as follows: Class I-seafloor; Class II-shallow burial; Class III - combined shallow burial - meteoric; and Class IV deep burial. These diagenetic classes are discussed further below.

\section{Seafloor (Class I)}

The diagenetic history of these limestones is unique amongst the diagenetic classes) because an extraordinary sombination of environmental and sedimentary conditions Fig. 9) has enabled the direct precipitation of marine vements within the seafloor deposits. Their overall occurrence is rare, and mainly in Oligocene-Miocene limestones. The special environmental conditions conducive to marine vementation are noted by Nelson \& James (1995) and nvolve: high water energies to achieve a high sea-water flux through the sediment; upwelling of cold nutrient-enriched waters over platform margins where they warm, loose $\mathrm{CO}_{2}$, and become supersaturated in $\mathrm{CaCO}_{3}$ (e.g., Wright 1994); a very coarse grained, often bryozoan-dominated sediment substrate having high porosity and permeability; a hiatus in sedimentation; and possibly a relatively lowered sea level. Thus, marine cementation is not pervasive but is limited to particular rock types which were subjected to specific environmental conditions. Class I limestones can be associated with genuine hardground formation and encrusting megafauna and borings, and also mineralisation by glauconite, and phosphatic and Fe-Mn compounds re.g., Watt 1972; Carter et al. 1982; Lewis \& Belliss 1984).

The marine cements typifying these limestones are first generation, fibrous to bladed isopachous rinds of nonferroan calcite with a non to dull CL. Porewards of the fringe spar cement, porosity is commonly occluded by polygenetic micrite (Fig. 8A). Some is internal sediment (microbioclastic micrite), derived from the mechanical abrasion and boring of skeletons, and pumped into cavities from the seafloor under relatively high energy environmental conditions. In contrast, much of the homogeneous and peloidal micrite is probably a true chemical precipitate (Nelson \& James 1995) formed wherever a very high flux of well-saturated sea water was maintained through the sediment pores. Either way, the micrite formation is associated with predominantly high energy conditions, not low as is commonly held for micrite (e.g., Reid et al. 1990). High energy conditions are also supported by the typically well abraded and sorted nature of many of the Class I limestones.

Once partially to well lithified at the seafloor, any marine-cemented sediment was slowly buried. Mechanical compaction was largely mitigated by the presence of the marine cements, as evidenced by the retention of relatively high interparticle porosities of $25-45 \%$. However, in the sporadically cemented or less well lithified deposits, increasing burial was accompanied by the onset of mild pressure-dissolution providing a second generation of calcite spar as syntaxial rims about echinoderm grains. An alternative minor source was the neomorphism of rare aragonitic skeletons preserved during initial burial. A third source of pore-occluding spar cement was from the associated sediments (either underlying or laterally equivalent) which did not experience early cementation, but otherwise underwent significant amounts of pressuredissolution during burial.

Another special feature of these limestones is the retention of evidence of the former existence of aragonite skeletons, despite the originally calcite dominant nature of the primary skeletal sediment. Marine cementation at the seafloor occurred sufficiently early to initially preserve any aragonite grains, which were subsequently dissolved at or near the seafloor to form biomoulds outlined by micrite envelopes, and subsequently infilled with equant calcite spar (Fig. 8A). Biomoulds of originally aragonitic skeletons are rare or absent in most other Oligocene-Miocene limestones 
(Classes II and IV) owing to the metastable nature of such grains in the nontropical setting, and their consequent dissolution and complete removal from the rock record before (burial) cementation occurred (e.g., Nelson et al. 1988).

\section{Shallow burial (Class II)}

The diagenetic history of those limestones assigned to Class II, predominantly of Oligocene--Miocene age but including some Pliocene occurrences, was controlled largely by the original skeletal mineralogy and individual basin tectonics (Fig. 9). Skeletal material of mixed mineral types, where calcite ( $\mathrm{LMC}$ ) > $>$ aragonite, was deposited and accumulated during conditions of relatively low sedimentation during an overall submergent (transgressive) event. Early diagenesis was dominantly destructive, the skeletons being subjected to fragmentation, reworking, abrasion, and bioerosion. The longevity of these seafloor processes, where grains possibly remained part of the periodically active bedload zone for up to thousands of years, appears to have been sufficient to have fostered the dissolution of any of the small amounts of aragonitic skeletal material present in the deposits (e.g., Beu et al. 1972). Consequently, the skeletal carbonate passing into the subsurface typically had a very low diagenetic potential, akin to LMC-dominated deep-sea calcitic oozes (Schlanger \& Douglas 1974). Any rare aragonite skeletons which survived into the burial realm were destined to dissolution or neomorphic transformation, and metastable $\mathrm{Mg}$-calcite skeletons experienced incongruent dissolution (Nelson 1978).

Early burial cements were sporadic and substrate specific, forming as bladed to dog-toothed, uneven spar fringes upon prismatic bivalves, or as syntaxial rim spar about echinoderm fragments. With increasing burial, grain realignment and rare skeletal fracturing occurred. Burial attained only shallow depths, from several tens of metres to a maximum of a few hundred metres (Nathan et al. 1986; Hayton 1995), sufficient to initiate mild pressure-dissolution between some calcitic skeletons and provide a meagre cement source for the more general precipitation of uneven and characteristically poorly developed spar fringes about open fabric skeletal grains (Fig. 8B).

Following uplift and exposure of the limestones to meteoric pore fluids, no further cementation has occurred, owing to the absence of any reactive metastable skeletons as a potential cement source. Consequently, Class II limestones are typically relatively soft, open, and porous, and make an ideal building stone, such as the "Oamaru stone" (Hayward 1987). They are analogous to many of the Oligocene-Miocene limestone occurrences in southern Australia described by James \& Bone (1991).

\section{Combined shallow burial - meteoric (Class III)}

Class III limestones characterise the Pleistocene and many Pliocene occurrences in North Island. Their diagenetic history was controlled by the interplay of tectonic processes, glacio-eustatic sea-level fluctuations, and the variable preservation of reactive, and locally dominant, infaunal aragonitic bivalves (Fig. 9). The diagenetic features of Class III limestones evolved during a dominantly emergent (regressive) event, and are intimately related to incursions of meteoric fluids and variable amounts of subaerial exposure (Haywick 1990). Many diagenetic features are diagnostic of the replacement of depositional marine fluids by reactive meteoric fluids, which have acted to dissolve: metastable aragonite and precipitate stable LMC.

Following the initial dominantly destructive diagenetic phase of mechanical and biological degradation at the seabed, relatively rapid burial occurred (Kamp \& Nelsol 1987), which deterred the early dissolution of much of th skeletal aragonite. During the shallowest depths of burial sporadic and limited amounts of nonferroan, dog-tooth fring cements of non to bright luminescence were precipitate (Fig. 8C, D). These cements rarely included nonferroar nonluminescent, acicular (originally ?aragonitic) fabrics. formed solely about aragonitic bivalves, whereas nonferroan to ferroan, bright to nonluminescent, scalenohedral to fibrous (probably MMC or HMC) fabrics formed about other skeletal grain types. The mobilisation of $\mathrm{Ca}^{2+}$ and $\mathrm{CO}_{3}^{2}$ during early localised aragonite dissolution, in the presence of $\mathrm{CaCO}_{3}$-undersaturated marine porewaters, is thought $t_{1}$ be ultimately responsible for much of the early sporadic cementation within the polymineralic limestones (Haywick 1990) which acted to preserve near-original intergranular pore volumes $(25-45 \%)$.

The introduction of varying amounts of microbioclasti micrite followed in some instances, infilling some of th already early cement-lined intraparticle and interparticle por: spaces, and must have taken place on the seafloor. Followin. these early diagenetic events of limited cementation, slow steady subsidence continued, and compaction acted to reduc interparticle pore volumes. Increased overburden pressures due to increased burial, resulted in the initiation of mil chemical compaction, dissolving skeletal grains unde: pressure in the presence of essentially marine fluids. Th: minor cement provided by mild pressure-dissolution wa: sometimes reprecipitated preferentially about echinodern grains as nonferroan, often complexly concentrically CI zoned syntaxial rim spar. Interparticle pore volume reduction by compaction was most significant in those limestones tha had not experienced some degree of lithification by early fringe cements.

Differential uplift and tilting of the limestones alon: basin margins (Kamp \& Nelson 1988; Kamp et al. 1988 ; enabled highly variable contact of the strata with recharging meteoric fluids while remaining predominantly in the shallow-burial environment (Haywick 1990). The degree of meteoric input was influenced also by Pliocene-Pleistocene glacio-eustatic sea-level fluctuations and the permeability of individual strata. Syntaxial rim cement and equant spar. which may have begun development in the subsurface sourced from aragonite dissolution and possibly pressuredissolution, continued to form once in the meteoric realm. given a cement donor. This cement was provided by two major sources: (1) from the wholesale dissolution of aragonitic bivalve grains, leaving empty biomoulds; and (2) by the neomorphic transformation of metastable aragonit: to stable LMC via thin-film transformation (Hood 1993).

Many biomoulds formed from wholesale dissolution are outlined by micritic envelopes formed by peripheral micritisation of skeletal grains by endolithic borers before grain dissolution. The evolution of secondary mouldic porosity has been most prevalent, and is most pronounced. in the Pleistocene limestones, perhaps as a consequence of their generally more prolonged exposure to meteoric fluid, with minimal overburden protection. The Pleistocent limestones are commonly riddled with dissolution moulds. corresponding to moderate cementation. 
Once porewaters became supersaturated with respect to $\mathrm{CaCO}_{3}$, neomorphic transformation of aragonite would have been the norm (Haywick 1990). Aragonite dissolution and LMC precipitation provided the cement source for the variably pore-filling micro-equant and equant spar cements. This also provided a source for the infilling of some dissolved aragonite moulds preserving micritic envelopes, which often remain as the only evidence of the former presence of aragonite grains. Despite the range of potential cement sources, the total occlusion of all intergranular pore space has been rarely achieved, pointing to an insufficient source (or time).

\section{Deep burial (Class IV)}

In this class, the Oligocene-Miocene limestones accumulated on shallow $(<200 \mathrm{~m})$ open shelves in agitated waters under regionally transgressive (submergent) conditions, much like the sediments of Classes I and II (Fig. 9) (Nelson 1978). Sediment accumulation rates were low, averaging $<5 \mathrm{~cm} / \mathrm{ka}$ (Nelson et al. 1988), although the figure is complicated by the occurrence of many diastems and unconformities in the limestones. Mechanical skeletal abrasion and bioerosion aided skeletal degradation. Micrite, dominantly formed from skeletal abrasion and boring, was washed or filtered into skeletal chambers and some interparticle pores at or near below the seafloor. Authigenic pyrite was precipitated, particularly in micritic sediments, as was glauconite in skeletal chambers. Early carbonate diagenesis appears to have been predominantly destructive and resulted in (1) the dissolution of any aragonitic skeletons before lithification and consequently their total loss from the rock record (Beu et al. 1972; Nelson 1978), and (2) the stabilisation to LMC of metastable $\mathrm{Mg}$-calcite skeletons by incongruent dissolution (Nelson 1978).

The precipitation of nonferroan syntaxial rim cements with dull CL about echinoderm grains probably began close to the seabed, and may have been sourced from aragonite dissolution. Mechanical and mild chemical compaction during the first few $100 \mathrm{~m}$ of burial provided a cement source for the continued preferential formation of nonferroan zoned luminescent syntaxial rim cement about the echinoderm material. Nelson et al. (1988) defined this shallow phase of burial as continuing to average sub-bottom depths of 500 $600 \mathrm{~m}$, during which time a porosity loss of $25 \%$ was achieved by physical compaction alone. With further burial, the development of echinodermal syntaxial cement continued, which became usually ferroan with increasingly reducing conditions and rising temperatures. These syntaxial rim cements typically are variably luminescent, but overall exhibit a non-bright-dull-bright-dull CL zonation with increasingly reducing conditions, consistent with that predicted for a subsidence-controlled cement sequence (Velson et al. 1988).

Nelson et al. (1988) argued for the onset of particularly widespread and intensive pressure-dissolution phenomena in the deposits beyond a critical chemical compaction threshold burial depth of c. $500 \mathrm{~m}$. The dissolved carbonate precipitated in stress-free pore spaces, typically as coarse drusy ferroan equant burial spar, which constitutes on average $90 \%$ of the total cement in Class IV limestones (Nelson et al. 1988). Non-sutured and microstylolitic dissolution seams became ubiquitous over the burial interval from c. 500 to $1100 \mathrm{~m}$. By this stage, original pore space had been reduced by $70 \%$ and was occluded by burial spar (Nelson et al. 1988). Fracturing and vein infilling with coarse, typically dull luminescent ferroan equant spar resulted during burial maxima, whereas nonferroan sparfilled veins are associated with later uplift in the presence of circulating meteoric waters.

Following uplift and subaerial exposure, terrigenousdominated cement-poor dissolution seams have weathered back to leave the characteristic flags associated with many of the Class IV limestones. Today, in outcrop, the limestones are undergoing wholesale dissolution, with the formation of prominent karst topography (Williams 1992).

\section{THE TEMPERATE LIMESTONE DIAGENETIC MODEL}

Most published diagenetic studies have centred on Recent and Pleistocene carbonate sediments in tropical areas (e.g., Bathurst 1975; Flügel 1982; Scholle et al. 1983). Much less is known about the diagenetic features of nontropical carbonates, as exemplified by a range of limestones widely distributed in both age and geographical location throughout New Zealand.

The diagenesis of New Zealand nontropical limestones has been strongly influenced by the composition and degree of preservation of the original metastable skeletons, by the chemistry of the pore fluids, and by the period of residency of these pore fluids. In turn, these factors were controlled by a combination of different temperate-latitude depositional settings, their basinal tectonic histories, and the degree of influence of eustatic sea-level fluctuations (Fig. 9). Together these factors have been responsible for the evolution of four major diagenetic pathways for the limestones, related here to diagenetic classes (Fig. 11) and pictorially summarised in Fig. 12.

The primary mineralogy of nontropical skeletal carbonates is dominated by calcite (mainly LMC and MMC), although aragonite is locally common and can dominate (Fig. 4). Compared to the apparently more usual situation in many New Zealand limestones in which any aragonitic skeletons have tended to be dissolved and lost without evidence from the rock record during early diagenesis (Nelson 1978), the eastern North Island Pliocene-Pleistocene limestones associated with overall regressive situations are compositionally distinctive because they preserve aragonite, or show evidence of its former existence as biomoulds or neomorphically stabilised skeletons. The reasons for the retention of aragonitic components in these limestones must be complex, given that in any one sample it may be possible to find: (1) original aragonitic skeletons; (2) former aragonitic skeletons now neomorphically transformed to LMC with the retention of much of their original shell microarchitecture; and ( 3 ) both empty and cement-filled dissolution moulds (Hood 1993). The relatively young age of these carbonates and their relatively rapid burial away from the seafloor in a dynamic tectonic system, coupled with glacio-eustatic sea-level fluctuations, are probably important controlling factors (Haywick 1990). The problem deserves future detailed study. Despite the occurrence of MMC and HMC skeletons in modern New Zealand carbonate sediments, their absence from all limestones in this study indicates early neomorphic stabilisation to $\mathrm{LMC}$ via incongruent dissolution. 


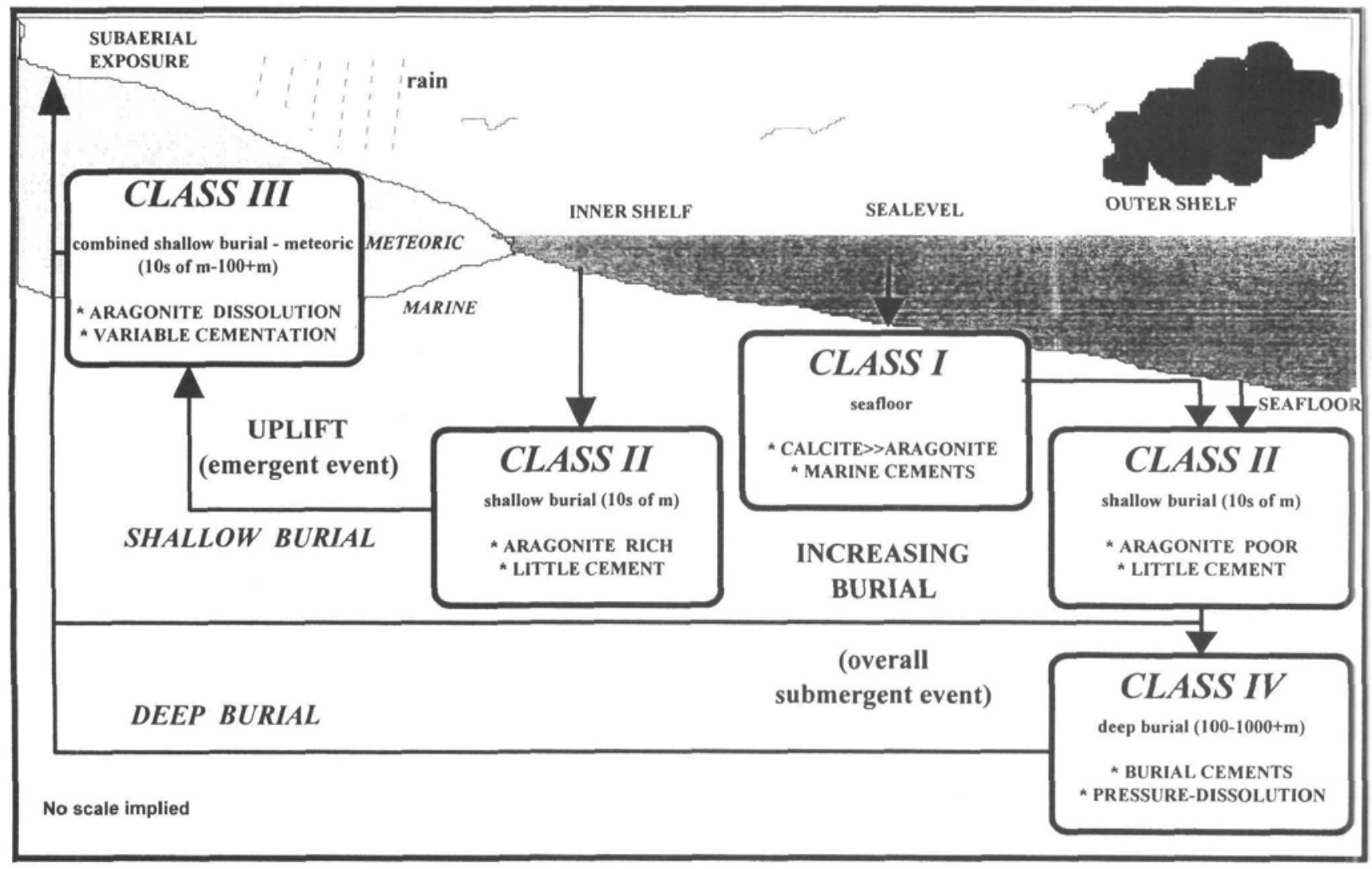

Fig. 12 Conceptual and idealised diagenetic model for New Zealand Cenozoic limestones. See Fig. 10 for details of the diagenetic features of Classes I-IV.

Early diagenesis in temperate New Zealand limestones was dominantly destructive owing to biological and mechanical erosion, and also commonly involved dissolution of metastable skeletal aragonite. The formation of synsedimentary marine cements in nontropical limestones has been rarely documented in the literature on modern and ancient temperate carbonates, but they have been identified in the New Zealand Oligocene-Miocene limestones (Nelson \& James 1995) and in age-equivalent limestones in southern Australia (James \& Bone 1992), sometimes associated with hardground faunas. Despite cool water temperatures, reduced carbonate saturation levels, and relatively high $\mathrm{CO}_{2}$ concentrations, these fibrous to bladed isopachous cements have apparently often formed under specialised environmental conditions associated with hiatuses in sedimentation. Their origin(s) require more specific study.

The common occurrence of variable, but sometimes significant, quantities of micritic carbonate in many New Zealand limestones, probably of both internal sediment and chemical precipitate origin, is largely undocumented in the temperate carbonate literature.

Current shallow-marine temperate-latitude carbonate sedimentation models are still evolving. It will be necessary for them to incorporate much of the diversity and complexity of a broad spectrum of skeletal facies and diagenetic features such as identified in this study. Features such as marine cements and associated hardground development, skeletal aragonite diagenesis, and the nature and origins of micritic carbonate, will necessitate an expansion and greater diversification of the shallow-marine nontropical carbonate model in the future. Further development of the model will require considerably more extensive and detailed studies ir order to continue to better understand the complex and as yet poorly understood group of shallow-marine sedimentary rocks collectively referred to as nontropical limestones.

\section{ACKNOWLEDGMENTS}

Funding support for fieldwork on the New Zealand limestones was kindly provided by a grant (Z557) from the University of Waikato Research Committee. Several persons offered logistical support of the project in various ways, including Bruce Haywarc (Auckland Museum), Mike Isaac and Alan Beu (Institute of Geological and Nuclear Sciences (IGNS), Lower Hutt), Davic Hood (New Zealand Qualifications Authority, Wellington), Daphne Lee (Geology Department, University of Otago), Doug Lewis (Geology Department, University of Canterbury), and Peter Barrett (Research School of Earth Sciences, Victoria University). The manuscript benefitted from the review comments of Roger Briggs and Shaun Hayton (Department of Earth Sciences, University of Waikato), Chris Hendy (Department of Chemistry, University of Waikato), David Smale (IGNS, Lower Hutt), and Harvey Young (Department of Geology, Brandon University, Canada).

\section{REFERENCES}

Alexandersson, E. T. 1978: Destructive diagenesis of carbonate sediments in the eastern Skagerrak, North Sea. Geology 6: 324-327.

Anderson, J. M. 1984: The sedimentology and diagenesis of an Oligocene carbonate sequence (Nile Group), Westport to Punakaiki. Unpublished M.Sc. thesis, lodged in the Library, Victoria University of Wellington, New Zealand. 
Bathurst, R. G. C. 1975: Carbonate sediments and their diagenesis. Amsterdam, Elsevier Scientific Publications. $658 \mathrm{p}$.

Beu, A. G.; Henderson, R. A.; Nelson, C. S. 1972: Notes on the taphonomy and paleoecology of New Zealand Tertiary Spatangoida. New Zealand journal of geology and geophysics 15: 275-286.

Carter, L. 1969: The Mahurangi Limestone from Puketotara Peninsula, Northland, New Zealand. New Zealand journal of geology and geophysics 12: $104-118$.

Carter, R. M.; Lindqvist, J. K.; Norris, R. J. 1982: Oligocene unconformities and nodular phosphate-hardground horizons in western Southland and northern West Coast. Journal of The Royal Society of New Zealand 12: 11-46.

Jobbie, W. A. 1982: Sedimentology and diagenesis of the Pukenui Limestone Formation, Wairarapa, New Zealand. Unpublished M.Sc. thesis, lodged in the Library, Victoria University of Wellington, New Zealand.

Hügel, E. 1982: Microfacies analysis of limestones. Berlin, Springer-Verlag. $633 \mathrm{p}$.

Harmsen, F. J. 1984: Stratigraphy, depositional history, and diagenesis of the Te Aute Group, a Pliocene temperate carbonate-bearing sequence in southern Hawke's Bay, New Zealand. Unpublished Ph.D. thesis, lodged in the Library, Victoria University of Wellington, New Zealand.

Harmsen, F. J. 1985: Lithostratigraphy of Pliocene strata, Central and Southern Hawke's Bay, New Zealand. New Zealand journal of geology and geophysics 28: 413-433.

Harris, G. J. 1986: Aspects of carbonate diagenesis of nontropicallatitude shelf limestones of the Late Paleogene Te Kuiti Group, South Auckland region, New Zealand. Unpublished M.Sc. thesis, lodged in the Library, University of Waikato, Hamilton, New Zealand.

Hayton, S. 1995: Skeletal assemblages and diagenetic aspects of non-tropical Cenozoic limestones, South Island, New Zealand. Unpublished M.Sc. thesis, lodged in the Library, University of Waikato, Hamilton, New Zealand.

Hayton, S.; Nelson, C. S.; Hood, S. D. 1995: A skeletal assemblage classification system for non-tropical carbonate deposits based on New Zealand Cenozoic limestones. Sedimentary geology 100: 123-141.

Hayward, B. W. 1987: Granite and marble: a guide to building stones in New Zealand. Geological Society of New Zealand guidebook $8.56 \mathrm{p}$.

Yaywick, D. W. N. 1990: Stratigraphy, sedimentology, paleoecology and diagenesis of the Petane Group (PliocenePleistocene) in the Tangoio Block, central Hawke's Bay, New Zealand. Unpublished Ph.D. thesis, lodged in the Library, James Cook University of North Queensland, Australia.

tood, S. D. 1993: Skeletal and diagenetic petrofacies of temperatelatitude limestones, North Island, New Zealand. Unpublished M.Sc. thesis, lodged in the Library, University of Waikato, Hamilton, New Zealand.

tornibrook, N. de B. 1992: New Zealand paleoclimates: a review based on the distribution of some shallow water and terrestrial biota. In: Tsuchi, R.; Ingle, J. C. Jr. ed. Pacific Neogene environment, evolution, and events. Tokyo, University of Tokyo Press. Pp. 83-106.

fyden, F. M. 1979: Mid-Tertiary temperate shelf bioclastic limestones, Southland, New Zealand. Unpublished Ph.D. thesis. lodged in the Library, University of Otago, Dunedin, New Zealand.

fames, N. P.; Bone. Y. 1991: Origin of a cool-water, OligoceneMiocene deep shelf limestone, Eucla Platform, southern Australia. Sedimentology 38: 323-341.
James, N. P.; Bone, Y. 1992: Synsedimentary cemented calcarenite layers in Oligocene-Miocene shelf limestones, Eucla Platform, southern Australia. Journal of sedimentary petrology 62: 860-872.

Kamp, P. J. J.; Nelson, C. S. 1987: Tectonic and sea-level controls on non-tropical Neogene limestones in New Zealand Geology 7: 610-613.

Kamp, P. J. J.; Nelson, C. S. 1988: Nature and occurrence of modern and Neogene active margin limestones in New Zealand. New Zealand journal of geology and geophysics 31: $1-20$.

Kamp, P. J. J.; Harmsen, F. J.; Nelson, C. S.; Boyle, S. F. 1988 Barnacle-dominated limestone with giant cross-beds in a non-tropical, tide-swept, Pliocene forearc seaway, Hawke's Bay, New Zealand. Sedimentary geology 60: 173-196.

Lawrence, M. J. F. 1989: Chert and dolomite in the Amuri Limestone Group and Woolshed Formation, eastern Marlborough, New Zealand. Unpublished Ph.D. thesis, lodged in the Library, University of Canterbury, Christchurch, New Zealand.

Leask, W. L. 1980: Basin analysis of Tertiary strata in Golden Bay, Nelson. Unpublished M.Sc. thesis, lodged in the Library, Victoria University of Wellington, New Zealand.

Leonard, J. E.; Cameron, B.; Pilkey, O. H.; Friedman, G. M. 1981: Evaluation of cold-water carbonates as a possible paleoclimatic indicator. Sedimentary geology 28: 1-28.

Lewis, D. W. 1992: Anatomy of an unconformity on mid-Oligocene Amuri Limestone, Canterbury, New Zealand. New Zealand journal of geology and geophysics 35: 463-475.

Lewis, D. W.; Belliss, S. E. 1984: Mid-Tertiary unconformities in the Waitaki Subdivision, North Otago. Journal of The Royal Society of New Zealand 14: 251-276.

Maliva, R. G.; Dickson, J. A. D. 1992: The mechanism of skeletal aragonite neomorphism: evidence from neomorphosed molluscs from the upper Purbeck Formation (Late Jurassic-Early Cretaceous), southern England. Sedimentary geology 76: 221-232.

Nathan, S.; Anderson, H. J.; Cook, R. A.; Herzer, R. H.; Hoskins, R. H.; Raine, J. I.; Smale, D. 1986: Cretaceous and Cenozoic sedimentary basins of the west coast region, South Island, New Zealand. New Zealand Geological Survey basin studies 1 .

Nelson, C. S. 1968: Sedimentology of redeposited calcareous and glauconitic beds at Pahaoa, south-east Wellington. Transactions of The Royal Society of New Zealand 6: 4562.

Nelson, C. S. 1973: Stratigraphy and sedimentology of the Te Kuiti Group in Waitomo County, South Auckland. Unpublished $\mathrm{Ph} . \mathrm{D}$. thesis, lodged in the Library, University of Auckland, Auckland, New Zealand.

Nelson, C. S. 1978: Temperate shelf carbonate sediments in the Cenozoic of New Zealand. Sedimentology 25: 737-771.

Nelson, C. S. 1988: An introductory perspective on non-tropical shelf carbonates. Sedimentary geology 60:3-14.

Nelson, C. S.; James, N. P. 1995: Some preliminary observations on marine cements in Oligocene-Miocene shelf limestones from New Zealand: an enigma or the norm in the nontropical carbonate model? In: Abstracts, Cool and Coldwater Carbonate Conference, Geelong, Australia. Sedimentology Studies Group, Geological Society of Australia. Pp. 54-56.

Nelson, C. S.; Harris, G. J.; Young, H. R. 1988: Burial-dominated cementation in non-tropical carbonates of the Oligocene Te Kuiti Group, New Zealand. Sedimentary geology 60: $233-250$ 
Reid, R. P.; Maclntyre, I. G.; James, N. P. 1990: Internal precipitation of microcrystalline carbonate: a fundamental problem for sedimentologists. Sedimentary geology 68 : 163-170.

Saller, A. H. 1992: Calcitization of aragonite in Pleistocene limestones of Enewetak Atoll, Bahamas, and Yucatanan alternative to thin-film neomorphism. Carbonates and evaporites 7: 56-73.

Schlanger, S. O.; Douglas, R. G. 1974: The pelagic ooze-chalklimestone transition and its implications for marine stratigraphy. In: Hsü, K. J.; Jenkyns, H. C. ed. Pelagic sediments on land and under the sea. International Association of Sedimentologists special publication 1: 117-148.

Scholle, P. A.; Bebout, D. G.; Moore, C. H. ed. 1983: Carbonate depositional environments. American Association of Petroleum Geologists memoir 33: 708 p.

Scoffin, T. P. 1987: An introduction to carbonate sediments and rocks. London, Blackie and Son.
Smith, A. M.; Nelson, C. S. 1994: Selectivity in sea-floor processes taphonomy of bryozoans. In: Hayward, P. J.; Ryland, J. S. Taylor, P. D. ed. Biology and palaeobiology of bryozoans Denmark, Olsen and Olsen. Pp. 177-180.

Watt, D. E. 1972: A study on a mid-Tertiary unconformity at Gee' Bay and in the Oamaru district. Unpublished B.Sc. (Hors thesis, lodged in the Library, University of Otago, Dunedin New Zealand.

Williams, P. W. 1992: Karst in New Zealand. In: Soons, J. M. Selby, M. J. ed. Landforms of New Zealand. 2nd. ed. Nev Zealand, Longman Paul. Pp. 187-209.

Wright, P. V. 1994: Early Carboniferous carbonate systems: ar alternative to the Cainozoic paradigm. Sedimentar geology 93: 1-5.

Young, H. R.; Nelson, C. S. 1988: Endolithic biodegradation of cool-water skeletal carbonates on Scott Shelf, northwestem Vancouver Island, Canada. Sedimentary geology 60 $251-267$ 